
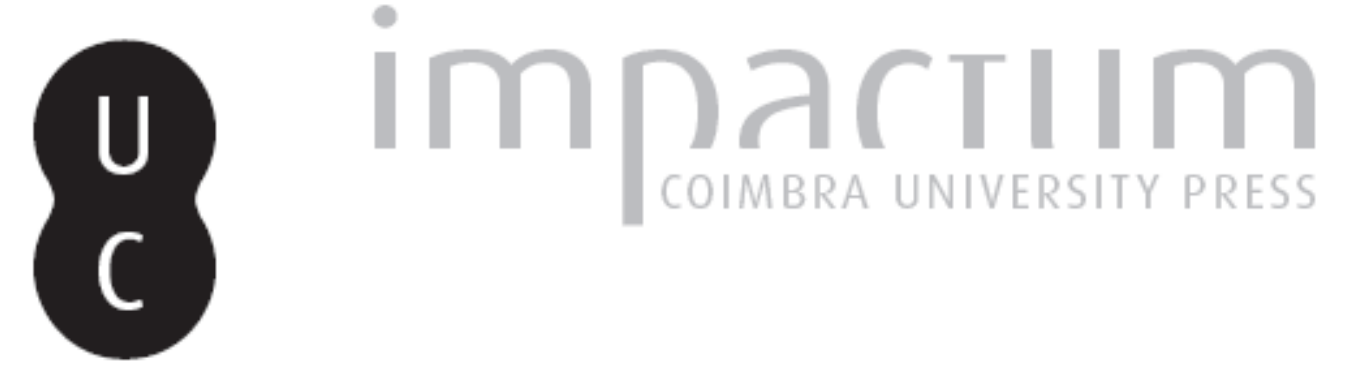

\title{
Do radicalismo igualitário grego ao universalismo conservador romano: a construção da ideia de república no estoicismo
}

Autor(es): $\quad$ Matos, Andityas Soares de Moura Costa

Publicado por: Annablume Clássica; Imprensa da Universidade de Coimbra

URL persistente:

URI:http://hdl.handle.net/10316.2/24304

DOI:

DOI:http://dx.doi.org/10.14195/1984-249X_9_5

Accessed : $\quad$ 26-Apr-2023 13:52:45

A navegação consulta e descarregamento dos títulos inseridos nas Bibliotecas Digitais UC Digitalis, UC Pombalina e UC Impactum, pressupõem a aceitação plena e sem reservas dos Termos e Condições de Uso destas Bibliotecas Digitais, disponíveis em https://digitalis.uc.pt/pt-pt/termos.

Conforme exposto nos referidos Termos e Condições de Uso, o descarregamento de títulos de acesso restrito requer uma licença válida de autorização devendo o utilizador aceder ao(s) documento(s) a partir de um endereço de IP da instituição detentora da supramencionada licença.

Ao utilizador é apenas permitido o descarregamento para uso pessoal, pelo que o emprego do(s) título(s) descarregado(s) para outro fim, designadamente comercial, carece de autorização do respetivo autor ou editor da obra.

Na medida em que todas as obras da UC Digitalis se encontram protegidas pelo Código do Direito de Autor e Direitos Conexos e demais legislação aplicável, toda a cópia, parcial ou total, deste documento, nos casos em que é legalmente admitida, deverá conter ou fazer-se acompanhar por este aviso.

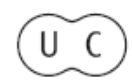




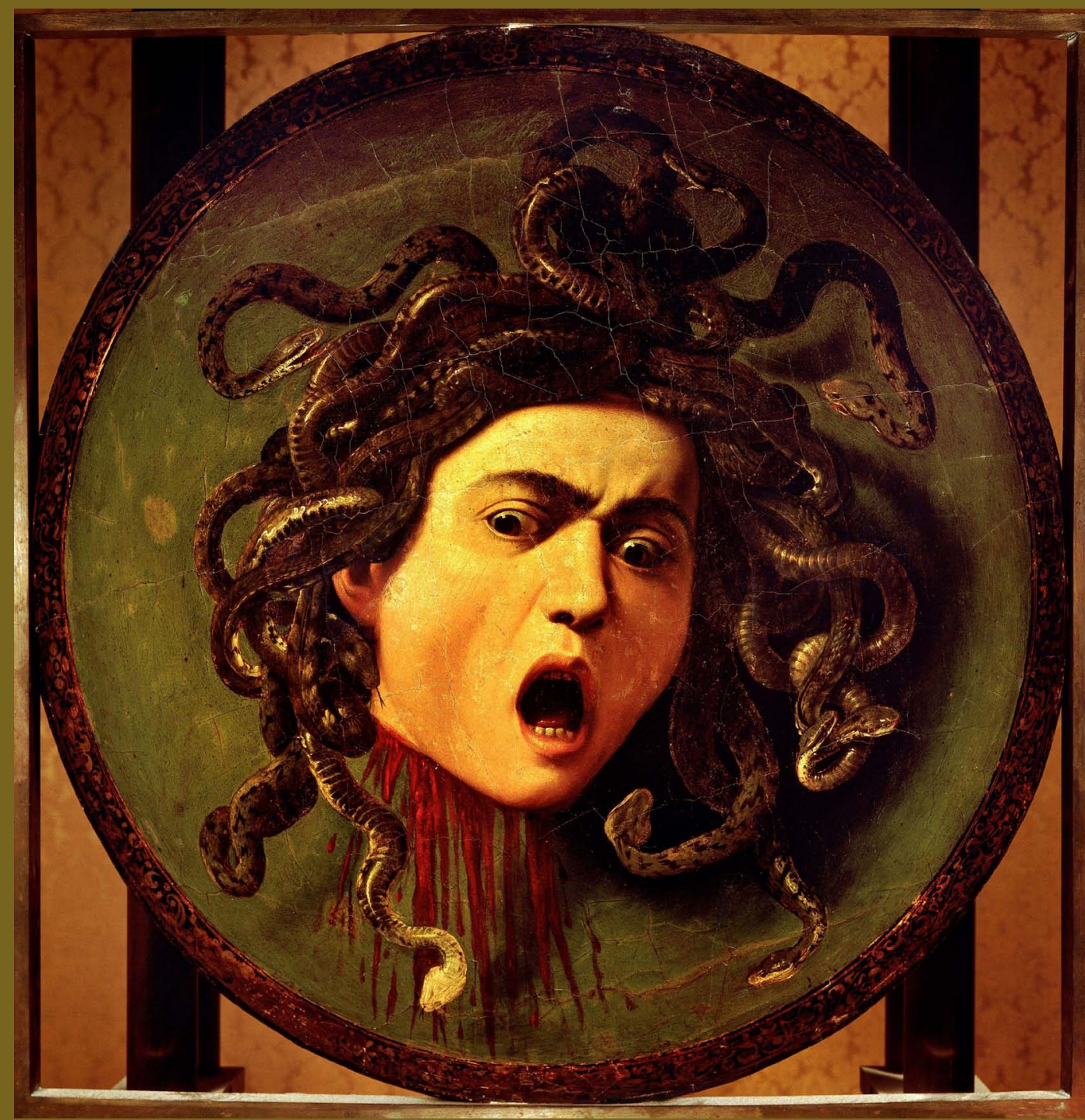

\section{R E V I S T A}
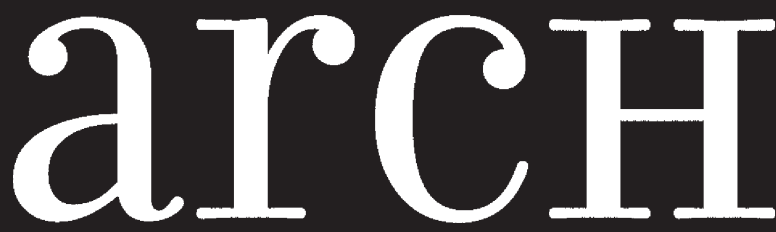
AS ORIGENS DO PENSAMENTO OCIDENTAL

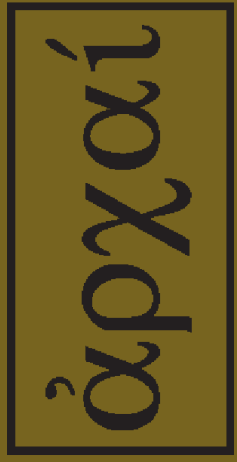

ARCHAI JOURNAL: ON THE ORIGINS OF WESTERN THOUGHT
arcHaI

arementam

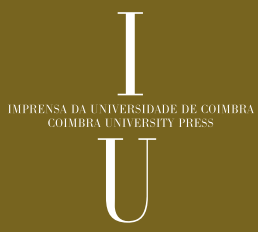

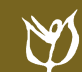

NNN 


\section{DO RADICALISMO IGUALITÁRIO GREGO AO UNIVERSALISMO CONSERVADOR ROMANO: A CONSTRUÇÃO DA IDEIA DE REPÚBLICA NO ESTOICISMO}

MATOS, A. S. M. (2012). “Do radicalismo igualitário grego ao universalismo conservador romano: a construção da ideia de República no Estoicismo". Archai n. 9, jul-dez 2012, pp. 45-60.

RESUMO: 0 objetivo do presente artigo é discutir a concepção de Direito, Justiça e Estado no pensamento estoico greco-romano, demonstrando a atualidade do tema e suas conexões com problemas contemporâneos tratados pela Filosofia do Direito, tais como os da legitimidade do poder e do universalismo da ordem jurídica. Em um primeiro momento são apresentados e problematizados elementos centrais da filosofia estoica, tais como as noções de lei natural, liberdade interior, igualdade formal e universalismo. Em seguida, mediante uma análise histórica e filosófica de caráter crítico-comparativo são apresentados os três principais projetos de república pensados pelos estoicos: 1) a república radical e igualitarista de Zenão (ap. 334 a.C. - 262 a.C.), na qual se nega a juridicidade, eis que o direito é entendido como construção artificial que impede a fruição da liberdade; 2) a república legalista de Cícero (106 a.C. - 43 a.C.), quando o direito natural é positivado para servir enquanto instância racional de auto-reflexão e de auto-fundamentação das normas jurídico positivas e, finalmente, 3) a "república" de Sêneca (4 a.C. - 65 d.C.), na qual o direito inicialmente se deixa absorver pelo poder pessoal do Imperador Romano para, em um segundo momento, mostrar-se como elemento universal, preparando assim as bases para a futura concepção de direitos fundamentais própria da modernidade.

PALAVRAS-CHAVE: Filosofia do Direito; Filosofia antiga; Estoicismo; República; Cosmópolis.

Abstract: The purpose of the present study is to discuss the concept of Law, Justice and State in the Greco-Roman Stoic
* Professor Adjunto de Filosofia do Direito e disciplinas afins na Faculdade de Direito da UFMG. Membro do Corpo Permanente do Programa de Pós-Graduação em Direito da UFMG. E-mail: vergiliopublius@hotmail.com

1. Nas citações de textos clássicos cuja edição utilizada é o volume Les stoïciens da Gallimard, obra organizada por PierreMaxime Schuhl, indicamos o autor e o título do

tratado em questão - no caso acima, trata-se

por exemplo, do Vies et opinions des philosophes de

Diógenes Laércio -, bem como a exata localização da passagem citada. 0 mesmo procedimento foi seguido quando utilizamos a edição de Anthony A. Long e David

N. Sedley, The hellenistic philosophers, que reúne em dois extensos volumes - 0 primeiro com as traduções $e$ os respectivos comentários e o segundo com os textos originais greco-latinos alguns fragmentos essenciais

e quase sempre raros da filosofia helenística.

\section{Andityas Soares de Moura Costa Matos}

\section{Introdução}

Cumpre anotar de início que estamos cientes da advertência de Veyne, para quem não existe propriamente uma teoria política estoica, visto que a Stoá teria construído uma moral voltada para a salvação individual do homem. Com os termos vagos do estoicismo, que impossibilitam pensar em políticas concretas e reduzem o problema da moralidade ao da racionalidade, seria possível justificar ou refutar tudo, desde filosofias da submissão até libelos revolucionários (VEYNE, 1996, p. 154), outro motivo que indicaria a inexistência de uma específica teoria estoica do Estado. No mesmo sentido, Tatakis se espanta pelo fato de o estoicismo, doutrina prática por excelência, não ter produzido nenhum grande homem de Estado, explicando tal paradoxo mediante a tese central do Pórtico segundo a qual a liberdade deve ser construída no recesso íntimo e não no mundo exterior, onde não há lugar para a autonomia (TATAKIS, 1931, p. 211).

Ambas as críticas são infundadas. Apesar de somente Cleantes ter designado a Política como parte autônoma do curriculum filosófico do Pórtico (DIOGÈNE LAËRCE, Vies et opinions des philosophes, VII, 41, SCHUHL, 2002, p. 30), ${ }^{1}$ boa parte dos demais filósofos estoicos gregos e romanos se dedicaram 
Philosophy by demonstrating the contemporaneity of the theme and its connections with actual problems considered by Philosophy of Law, such as the legitimacy of power and the universalism of the legal order. Firstly, central elements of the Stoic Philosophy will be presented and questioned, such as the notions of natural law, inner freedom, formal equality and universalism. Subsequently, through a philosophical and historical analysis shaped by a critical and comparative method, three main projects of the Republic as thought by the Stoics are presented: 1) the radical and egalitarian republic of Zeno of Elea (ca. 334 BC - ca. 262 $B C)$, in which the idea of juridical order is denied, as Law is understood as an artificial construction that impedes the fruition of freedom; 2) the legalistic republic of Cicero (106 $B C-43 B C$ ), when natural law was established to serve as a rational auto-reflective instance and also as a self-support to the legal-positive laws and, finally; 3 ) the "republic" of Seneca (4 $B C-65 A C)$, in which Law initially let itself be absorbed by the personal power of the Roman Emperor to, in a second moment, show itself as an universal element and prepare the basis to the future concept of fundamental rights, which is characteristic of the modernity.

KEYWORDS: Philosophy of Law; Ancient Philosophy; Stoicism; Republic; Cosmopolis.

a tal tema no contexto da Ética. Pelo menos três deles - Zenão, Crisipo e Panécio ${ }^{2}$ - escreveram tratados políticos sistemáticos, sem contar os de Cícero, que não é propriamente um filósofo estoico, como demonstramos em nossa obra (MATOS, 2009, pp. 5-7). Se é verdade que os estoicos gregos não participaram ativamente da política, ideia que nos parece discutível (MATOS, 2009, pp. 215-241), tal conclusão se revela absolutamente falsa em relação ao estoicismo médio e ao Pórtico imperial, correntes que produziram um Panécio, conselheiro de Cipião; um Cícero, cônsul e senador da República Romana; um Sêneca, preceptor do Princeps e senador; e, por fim, como coroamento da Stoá, um Marco Aurélio, Imperador de Roma.

0 unitarismo informa todo o pensamento estoico, de modo que a proposta de construção do novo homem encontra sua contrapartida necessária na instituição das condições sociais concretas capazes de educar e de formar o ser humano universal: “Modifica-se a teoria sobre a cidadania em função de uma reflexão ímpar sobre o modo de ser do cosmos e do homem. A ordem do todo deve expressar, para um estoico, a união homem-natureza-lei-cidade" (GAZOLLA, 1999, p. 47). Arnold repudia a crença segundo a qual a teoria do Estado estoica seria secundária e se subordinaria à Ética individualista do Pórtico. Na verdade, a Ética estoica não é individualista e se fundamenta na lei cósmica, comum a todos os seres. A normatividade universal e a lei moral interior são apenas faces da mesma moeda. Dessa maneira, não podemos desprezar a concepção de Estado gestada pelo estoicismo (ARNOLD, 1971, pp. 274-275).

Como veremos, o problema do Estado foi tratado pelos filósofos estoicos de maneira inédita na Antiguidade, ${ }^{3}$ ainda que não possamos falar nesse período propriamente em "Estado" no sentido técnico-jurídico do termo, ${ }^{4}$ eis que essa específica forma de organização social surgiu apenas com a centralização do poder real no final da Idade Média. Contudo, Cícero nos oferece uma definição lata e conceitua "Estado" como qualquer sociedade de homens formada sob o império do direito (iuris societas) (CÍCER0, 1973, VI, VI, p. 186). Independentemente de conceituações acadêmicas, a sociedade política enquanto tal foi objeto da assídua reflexão da Stoá, seja em sua versão grega ou, com muito mais profundidade, na sua versão imperial. 0 tema-base que animou ambas as correntes foi 0 incipiente internacionalismo cosmopolita político-jurídico, a cidadania universal fundada em uma noção também universal de direito e de justiça. 0 estoicismo grego se desenvolveu no contexto da helenização do mundo possibilitada pelas conquistas de Alexandre, experiência imediata do universal concretizada pelos romanos da fase imperial. Com o desenvolvimento do Império, as fronteiras entre os povos já nada significavam para o ciuis, conceito jurídico cada vez mais alargado pelo Direito Romano que, à semelhança do que pregavam os estoicos, mais e mais se aproximava daquela lei ideal e universal apta a reger todo o gênero humano. Zenão jamais poderia imaginar que as suas teorias teriam tamanha repercussão, fundamentando o direito de uma estrutura política universal como o foi o Império Romano.
2. Assim como nos casos de Zenão e de Crisipo, o texto de $A$ república de Panécio encontra-se perdido. Sobreviveram apenas alguns poucos fragmentos nos quais se percebe que a obra versava sobre o tópico tradicional da melhor forma de governo, tendo Panécio se inspirado em diversos argumentos platônicos e aristotélicos. Cf. TATAKIS, 1931, p. 40.

3. A noção de cosmopolitismo político-jurídico não era nova no contexto do estoicismo, dado que Sócrates, Diógenes, o cínico e os epicuristas já conheciam e discutiam o tema (cf., p. ex., DIOGENES OF OENOANDA, Fragments, 24, 2, 3-11, LONG; SEDLEY, 2006, pp. 349-350). A novidade que os estoicos trouxeram ao debate foi 0 tratamento sistemático e racional do cosmopolitismo, dando origem a uma verdadeira teoria universal do Estado, algo até então impensável na Antiguidade.

4. Schofield entende que a ideia estoica de cidade se funda unicamente na postulação de uma comunidade que vive sob certas regras derivadas da razão, fenômeno que não dá lugar ao Estado. Para tanto seriam necessárias outras condições, tais como a centralização da autoridade e a divisão de poderes. Cf. SCHOFIELD, 1999, p. 73.

5. “Was Zeno's vision internationalist? It used to be thought so, on the strength of the Stoics' penchant for the expression 'citizen of the world' [...]. But Zeno's Republic itself hardly envisaged a world state. Is Plutarch's reading of Zeno as a theoretical exponent of the unification wich Alexander the Great 'realized in practice' by empire-building, and 'citizen of the world' has less to do with the United Nations than with the rationality all humans share with their divine ruler. What the Stoics did undoubtedly promote was a very powerfull conception of law as the basis of civic life. Their main contribution to internationalism was their treatment of moral principles as laws of human nature, transcending all accidents of birth and local identities. When Stoicism infiltrated the Roman Empire, these ideas found an environment larger than any that Zeno can have foreseen" (LONG; SEDLEY, 2006 , pp. 435-436). 


\section{Sociabilidade e cosmopolitismo}

0 ponto de partida dos estoicos no que concerne à teoria política é idêntico ao de Aristóteles. Cícero ensina que os homens não são apenas animais sociais, mas sim seres em que os laços de sociabilidade são os mais estreitos possíveis, motivo pelo qual um homem não deve jamais ser um estrangeiro para outro homem (CICÉRON, Des fins des biens et des maux, III, XIX, 63, SCHUHL, 2002, p. 285). 0 amor que os pais sentem pelos seus filhos constitui a prova inequívoca e o primeiro estágio da sociabilidade ínsita à espécie humana; se adequadamente desenvolvido, culminará de modo inevitável na postulação da sociedade universal (CICÉRON, Des fins des biens et des maux, III, XIX, 62, SCHUHL, 2002, p. 285). 0 estoico romano Hierócles acredita que estamos inseridos em vários círculos concêntricos: 0 primeiro inclui os nossos corpos e o último comporta todos os seres humanos, não sem antes passar pelas instâncias da família, dos amigos e dos concidadãos. Cabe ao sábio assimilar progressivamente um círculo ao outro, buscando concentrá-los em um só, de maneira que enxerguemos todos os seres humanos como elementos integrantes do primeiro ciclo, ou seja, partes do nosso próprio corpo (HIEROCLES apud STOBAEUS, Anthologium, IV, 671-673, LONG; SEDLEY, 2006, pp. 349-350). ${ }^{6}$

De acordo com Epicteto, a sociabilidade é natural ao homem, assim como as formas políticas mediante as quais tal impulso se concretiza (ÉPICTÈTE, Entretiens, II, XX, 6-8, SCHUHL, 2002, p. 937). Ao contrário do que afirmarão os contratualistas da Modernidade, para o Pórtico a vida social não nasce de pactos de não-agressão ou de deficiências do indivíduo, incapaz de sobreviver sozinho, mas de necessidades naturais - ou seja, racionais - dos seres humanos. Nossa sociabilidade natural se relaciona diretamente à moralidade porque o outro constitui não apenas o meio e a condição da virtude (CICÉRON, Des fins des biens et des maux, III, XX, 65-66, SCHUHL, 2002, pp. 286-287), mas também o seu próprio objetivo (CICÉRON, Des fins des biens et des maux, III, XX, 67-68, SCHUHL, 2002, p. 287). Nada existe de mais precioso para o homem do que os outros homens, dado que os seres humanos se pos- sibilitam mutuamente as circunstâncias necessárias para a vida, cada qual realizando determinada função tendo em vista o perfeito funcionamento do todo social (CÍCERO, 2000, II, 12-14, pp. 81-82). A preocupação com o outro coloca em relevo a dimensão social da virtude estoica, cuja quintessência somente pode ser a justiça (BERRAOND0, 1992, p. 111).

Aos estoicos parecia necessário infundir o sopro da razão cósmica na sociedade política, o que significa organizá-la por meio de esquemas racionais. 0 primeiro passo para tanto consistiu na assimilação dos típicos dualismos do poder político-jurídico da Antiguidade: de um lado, direito positivo/direito natural; de outro, comunidade/indivíduo (MATOS, 2009, pp. 241-252). Agindo assim, o Pórtico tornou possível a superação da nova díade surgida no período helenístico pós-alexandrino: cidade/império. 0 estoicismo imperial teve sucesso em sua empreitada universalizante justamente porque soube ultrapassar estes dualismos, anulando ${ }^{7}$ a primeira opção e privilegiando a segunda, com o que adotou um rígido princípio monista: o genuíno direito é o natural, moldado pela razão imanente ao cosmos e presente em cada um dos indivíduos, cidadãos do verdadeiro Estado cuja expressão histórica radica-se no império universal romano e não na pólis grega.

Tendo adotado tal perspectiva, Marco Aurélio afirma que todo homem é cidadão da cidade suprema do universo; lugares como Roma e Atenas nada são senão casas (MARCO AURÉLIO, 1973, III, 11, p. 282). Por sua vez, Sêneca entende que o homem vive em duas repúblicas: a primeira, grande e verdadeiramente pública, diz respeito a todos os seres humanos; a outra é a pátria assinalada a cada um de nós pelo acidente do nascimento (SÊNECA, 2001, IV, 1 p. 83). Diferentemente dos romanos, ao definirem "cidade" como uma comunidade de homens virtuosos vivendo sob a guarda de uma lei comum, os estoicos gregos concluíram que não existem verdadeiras cidades no mundo (DIO CHRYSOSTOM, Orationes, 36, 20, LONG; SEDLEY, 2006, p. 431 e STOBAEUS, Anthologium, II, 103, LONG; SEDLEY, 2006, p. 431). Por isso Diógenes de Babilônia disse que Roma não era uma cidade, eis que entre os loucos não há civilidade e nem direito (CICÉRON, Premiers académiques, II, XLV, 137, SCHUHL, 2002, p. 252). É que os estoicos gregos 
tinham por paradigma o Estado ideal imaginado por Zenão em sua República (Politeia). ${ }^{8}$ Convém dedicarmos algumas páginas à apresentação e à análise desse tratado, que apesar de ter sido célebre na Antiguidade, hoje está irrevogavelmente perdido.

\section{A República crítica de Zenão}

A tradição doxográfica ensina que a Politeia é uma obra da juventude de Zenão (n. ap. 334 a.C. - m. 262 a.C.), tendo sido influenciada pelo magistério cínico de Crates, de quem o futuro fundador da Stoá foi um aplicado discípulo (SELLARS, 2006, p. 129). Diógenes Laércio informa que a Politeia foi escrita na "cauda do cão" (DIOGÈNE LAËRCE, Vies et opinions des philosophes, VII, 4, SCHUHL, 2002, p. 18), ou seja, enquanto Zenão encontrava-se influenciado pelos cínicos, filósofos que se autodenominavam cães, eis que a sua ética naturalista e afrontosa à moral média grega se desenvolveu no ginásio Cynosarges ("o cão agil") (SCHUHL, 2002 [p. 18, n. 2], p. 1252). Filodemo, epicurista do século I de nossa era, aduz que Zenão escreveu a Politeia durante os anos de juventude, motivo pelo qual a obra seria desavergonhada e ímpia (ERSKINE, 1990, p. 10).

Erskine é bastante cauteloso e entende que as evidências doxográficas são insuficientes para que qualifiquemos a República de Zenão como obra juvenil (ERSKINE, 1990, pp. 9-14). Tanto Diógenes Laércio quanto Filodemo escreveram em contextos nos quais se buscava reabilitar o estoicismo diante da sociedade romana, o que incluía o encobrimento de seus traços cínicos ou pelo menos a relativização da importância de escritos obscenos e moralmente agressivos como a Politeia de Zenão, que causava grande embaraço aos estoicos de Roma (ERSKINE, 1990, p. 206). Diógenes Laércio nos conta que Atenodoro - filósofo estoico e chefe da biblioteca de Pérgamo - chegou a suprimir dos textos estoicos todas as passagens julgadas indecentes e vergonhosas; elas foram reintegradas às respectivas obras somente após a descoberta da ilegítima censura levada a efeito por Atenodoro (DIOGÈNE LAËRCE, Vies et opinions des philosophes, VII, 34, SCHUHL, 2002, p. 28). Mas por que censurar uma simples obra de juventude? Por que os estoicos do século
I d.C. se preocupavam tanto em afirmar o caráter imaturo do texto político de Zenão? A Erskine tais atitudes parecem claras indicações da feição madura do tratado. Ademais, a Politeia se mostra coerente com diversos aspectos da teoria do Pórtico que somente poderiam ter sido desenvolvidos por Zenão no final de sua carreira filosófica (ERSKINE, 1990, p. 15). Erskine também nega a natureza cínica do tratado em questão, que deveria muito mais a Platão do que a Antístenes e a seus discípulos (ERSKINE, 1990, p. 27).

Sendo ou não uma obra de juventude, a República de Zenão constitui o primeiro trabalho estoico inteiramente dedicado à discussão de temas político-jurídicos e como tal deve ser considerado, ainda que muitas das posições de Zenão sejam realmente polêmicas e apresentem nítida inspiração cínica. As suas concepções de Estado, Direito e Política se relacionam de modo direto à Ética dos cínicos, que desprezavam os padrões morais convencionais e pregavam formas utópico-anarquistas de organização social. Contudo, a proposta central do texto parece-nos legitimamente estoica: Zenão afirma que não devemos nos subordinar a cidades particulares e a ordenamentos jurídicos específicos porque todos nós somos cidadãos da república governada pela lei comum da razão (PLUTARCH, On the fortune of Alexander, 329 A-B, LONG; SEDLEY, 2006 , p. 429). Mas ele rapidamente acrescenta que a irmandade somente se dá entre homens virtuosos. Os demais, independentemente de posição social, grau de parentesco, poder econômico ou qualquer outro fator, devem ser tratados como inimigos, escravos e estrangeiros (DIOGÈNE LAËRCE, Vies et opinions des philosophes, VII, 32, SCHUHL, 2002, pp. 27-28). Segundo Zenão, apenas os virtuosos - $i$. e., os sábios - são livres, pois só eles se mostram capazes de ações autônomas (CICÉRON, Premiers académiques, II, XLIV, 136, SCHUHL, 2002, p. 251 e DIOGÈNE LAËRCE, Vies et opinions des philosophes, VII, 121, SCHUHL, 2002, p. 55). Todos os outros seres humanos não passam de escravos e, como tal, não participam da república universal.

No Estado ${ }^{9}$ imaginário de Zenão restam abolidas a propriedade privada e a moeda, além de ser proibida a construção de ginásios, templos
8. Além das já citadas obras monográficas de Erskine e de Schofield, o texto básico sobre a república zenoniana é o artigo de BALDRY, 1959, pp. 3-15.

9. 0 vocábulo "Estado" não é o mais adequado para descrevermos a comunidade política igualitarista propugnada por Zenão. Com base nas teses de Pierre Clastres, Gazolla compara a pólis ideal de Zenão às chamadas "sociedades sem Estado". Nelas impera a homogeneidade social e inexistem órgãos separados de poder, de modo que este não se aliena da sociedade (GAZOLLA, 1999, p. 72). Cf. CLASTRES, 1982, p. 106. 
e tribunais. 0 curriculum educacional tradicional grego (enkuklios paideia) é declarado inútil (DIOGÈNE LAËRCE, Vies et opinions des philosophes, VII, 32, SCHUHL, 2002, pp. 27-28). Homens e mulheres devem vestir-se de idêntica maneira; todavia, é preferivel que exponham ao ar livre o corpo descoberto (DIOGÈNE LAËRCE, Vies et opinions des philosophes, VII, 33, SCHUHL, 2002, p. 28 e PLUTARCH, On stoic self-contradictions, 1034 B, LONG; SEDLEY, 2006, p. 430). As mulheres são compartilhadas por todos os homens (DIOGÈNE LAËRCE, Vies et opinions des philosophes, VII, 33, SCHUHL, 2002, p. 28) e o trabalho manual é permitido aos cidadãos livres, o que não lhes acarreta qualquer desonra, ideia abertamente contrária à cultura greco-romana do otium intelectual, que reserva aos escravos todas as tarefas servis e

10. 0 canibalismo era um dos temas favoritos dos cínicos quando objetivavam chocar a sociedade grega. Segundo diziam, nada poderia haver de mais natural, pois existe somente uma única substância que se modifica incessantemente. Assim, ao comermos um pão ou a carne de outro homem não estamos realizando atos ontologicamente diversos, já que nos alimentamos sempre do mesmo corpo: o do universo. A antropofagia nos parece terrível porque come carne humana significa nega a possibilidade de ressurreição corporal e, implicitamente, de vida após a morte (ONFRAY, 2005, pp. 124-127). Vejamos, a respeito do canibalismo, a notícia de Diógenes

Laércio relativa a Diógenes, 0 cínico: "Ni siquiera le parecía impí el devorar trozos de carne humana, como ejemplificaba con otros povos. Incluso comentaba que, según la reta razón, todo estaba en todo y circulaba por todo. Así, por ejemplo, en el pan había carne y en la verdura pan, puesto que todos los cuerpos se contaminan con todos, interpenetrándose a través de ciertos poros invisibles y transformándose conjuntamente en exhalaciones" (DIÓGENES LAERCI0, 2007, VI, 73, p. 312). Não é preciso sublinhar que esta tese cínica se harmoniza com a Física da Stoá. Todavia, os estoicos ortodoxos justificavam a antropofagia apenas em casos específicos (DIOGÈNE LAËRCE, Vie et opinions des philosophes, VII,

121, SCHUHL, 2002, p. 54). 0 exemplo clássico é o do naufrágio (ARNIM, 1968, III, 748). braçais. Ainda há mais: na cidade ideal o sábio pode prostituir-se para ganhar a vida, o filho faminto está autorizado a devorar o cadáver de seu pai (ARNIM, 1968, I, 254) e as conversas longas entre homens nas barbearias são vetadas (VEYNE, 1996, p. 143). Não existem ritos funerários; os corpos dos mortos são entregues ao tempo ou às feras. Segundo Crisipo, o cadáver não tem mais importância do que as unhas ou os cabelos que perdemos ao longo da vida (ARNIM, 1968, III, 752). Aliás, Crisipo também escreveu um tratado político - Sobre a república - em que expõe concepções polêmicas muito semelhantes às de Zenão. Na cidade crisipiana é lícito que os filhos copulem com os pais, bem como a antropofagia ${ }^{10} \mathrm{e}$ a prática da sofística, já que para ganhar a vida 0 sábio pode vender seus conhecimentos, colocar-se a serviço de um rei ou buscar a proteção de amigos (DIOGÈNE LAËRCE, Vies et opinions des philosophes, VII, 188-189, SCHUHL, 2002, p. 78).

Opiniões assim perturbaram tanto os estoicos de Roma que alguns foram obrigados a sustentar que a República de Zenão era uma obra esotérica, voltada apenas para os discípulos mais avançados no estudo da doutrina do Pórtico (CLEMENT, Miscellanies, V, 9 , 58, 2, LONG; SEDLEY, 2006, p. 430). Outros, como Filodemo, viram nas licenciosidades da República o signo da imaturidade posteriormente superada pelo "verdadeiro" Zenão, comprometido com a ortodoxia estoica (SCHOFIELD, 1999, p. 9). Talvez com os olhos postos na Politeia, o circunspecto Cícero condenou os cínicos e alguns estoicos pela linguagem obscena que utilizavam em seus escritos. De acordo com 0 romano, precisamos diferenciar a indecência presente nos atos daquela que se verifica nas palavras, regra de decorum que Zenão certamente desprezaria. Assim, o roubo, a fraude e o assassinato são coisas moralmente más e vergonhosas. Entretanto, ao nos referirmos a elas não cometemos nenhuma falta moral. Lado outro, gerar filhos é moralmente bom, mas não podemos descrever o ato em si sem sermos indecorosos (CÍCERO, 2000, I, 128, pp. 6162). Com considerações assim Cícero se afasta da formulação original do Pórtico, que não admitia regras limitativas da linguagem, eis que ela existe para descrevermos o mundo tal como ele é, ainda que para tanto seja necessário lançarmos mão de termos pouco polidos ou torpes. Trata-se de chamar as coisas pelos seus verdadeiros nomes (ARNOLD, 1971, p. 288).

Apesar do ridículo de algumas das propostas antissociais do estoicismo grego - que valeram muitas críticas a todos os estoicos, até mesmo aos que eram avessos à Politeia de Zenão, como os romanos -, elas representam um inegável desafio, à moda irônica dos cínicos, aos costumes e às instituições então reinantes na decadente sociedade grega. 0 projeto zenoniano objetivava desmascarar a profunda irracionalidade que sub-repticiamente havia se infiltrado no pensamento grego. Na época de Zenão o irracionalismo já havia se cristalizado em argumentos conservadores que mantinham vivos preconceituosos rituais cívico-religiosos, a crença na inferioridade intelectual das mulheres e dos escravos e a valorização de elementos externos como marcas de virtude. Assim, a proibição da produção de moedas na república de Zenão representa uma provocação à ordem constituída, dado que a cunhagem configura-se como metáfora conglobante de todas as demais convenções sociais. Do mesmo modo, a abolição de templos, ginásios e cortes de justiça representa um feroz ataque às principais instituições da vida cívica grega (SCHOFIELD, 1999, p. 13). Conforme sugere Erskine, a interdição da construção de templos na cidade de Zenão indica que devemos honrar aos deuses não com suntuosos monumentos, mas pela prática constante da 
virtude, único adorno digno da pólis dos sábios. Por envolverem aspectos competitivos que não devem ser estimulados nos cidadãos, Zenão condena também os ginásios, inúteis na sua república. As cortes de justiça são igualmente dispensáveis em um Estado no qual todos são amigos, assim como a moeda parece ser de pouca valia em uma sociedade comunal na qual não há propriedade privada e tudo é partilhado (ERSKINE, 1990, p. 24). Por fim, com a instituição familiar e os tabus sexuais suprimidos, homens e mulheres devem usar roupas iguais para demonstrarem às crianças - ainda imaturas e, portanto, impressionáveis pelo aspecto exterior das coisas - a igualdade essencial existente entre todos os cidadãos (ERSKINE, 1990, p. 25).

Por fim, os estoicos gregos não viam qualquer problema no incesto, afinal de contas, em última análise todos somos irmãos. Aliás, na tradição grega Hera foi descrita como irmã e esposa de Zeus. A compreensão do incesto mediante a perspectiva racionalista dos estoicos levará Orígenes a questionar a sua proibição geral, postulando uma situação hipotética em que toda a raça humana tenha se extinguido, restando apenas um homem e sua irmã no planeta. Reproduzir-se seria um dever do casal, de modo a garantir a salvação da espécie, o que demonstraria a inexistência de vedação natural ao incesto. Sua proibição seria apenas mais uma convenção social (ARNOLD, 1971, pp. 277-278).

Não obstante o caráter chocante - e por isso mesmo pouco factível - de alguns dos planos sócio-políticos de Zenão, Fassò entende que a sua proposta não se confunde com os delírios fantásticos e mitológicos de muitos utopistas da época. A Politeia zenoniana parece-lhe radicalmente racional. Todos os seus excessos derivam da sistemática desconsideração da realidade histórica, postura típica de correntes que, tais como o estoicismo grego - não o romano -, adotam um rigoroso racionalismo abstrato como fundamento (FASSÒ, 2001, p. 86).

Já Gazolla pretende ver na república zenoniana mais um exemplo do que ela chama de "duplo registro da Stoá". Segundo explica a estudiosa, o discurso do estoicismo apresentaria feição ambivalente e contraditória devido a estratégias retóricas, de sorte que Zenão teria intenções críticas e para- digmáticas ao descrever o seu Estado ideal, ${ }^{11}$ que não se destinaria a existir na realidade concreta, servindo apenas como modelo para julgamento das sociedades reais (GAZOLLA, 1999, pp. 55-56). Na interpretação de Gazolla, a República de Zenão assume nítido caráter pedagógico, assim como o ideal do sábio perfeito. Ambas as ideias se revelam como metas a serem buscadas, não atingidas.

Por sua vez, Schofield apresenta três possibilidades de leitura (SCHOFIELD, 1999, p. 22) para a República de Zenão: a) Antinômica, da qual nenhuma doutrina política emergiria, dado que Zenão estaria preocupado apenas em criticar as instituições existentes e não em propor reformas sociais; b) Revisionista, segundo a qual Zenão teria inovado a Filosofia Política da Antiguidade ao delinear uma comunidade só de sábios e fundada na virtude; c) Comunitária, na linha da república de Platão. Por mais incriveis que possam parecer as propostas de Zenão, ele não teria concebido um Estado utópico, mas sim uma comunidade possível e relativamente perfeita na qual as virtudes dos cidadãos seriam garantidas por Eros, deus que manteria apertados os laços políticos graças à amizade e à concórdia que inspiraria nos indivíduos. Nesta última chave de leitura - que Schofield entende ser a mais adequada -, o Estado de Zenão nada teria de irrealizável, tendo sido destinado à concretização histórica mediante novas e racionais instituições sociais que promoveriam as virtudes cívicas do homem.

Como prova de correção da sua hermenêutica, Schofield cita duas passagens doxográficas. A primeira delas é um trecho de Diógenes Laércio no qual, à moda de Platão, afirma-se que Zenão e Crisipo entendiam que as mulheres deveriam ser tidas em comum pelos homens da república (DIOGÈNE LAËRCE, Vies et opinions des philosophes, VII, 131, SCHUHL, 2002, pp. 57-58). Elas manteriam relações sexuais de maneira indiscriminada para que as crianças delas nascidas fossem alvo de sentimentos paternais por parte de todos cidadãos. ${ }^{12}$ Como vantagem adicional da poligamia teríamos ainda a extinção do ciúme e do adultério, males extremamente prejudiciais à coesão social de qualquer comunidade política. Tal testemunho parece suficiente a Schofield para comprovar que a república de Zenão pretende assegurar
11. "Imaginar uma cidade que não seja a vivenciada, ou futuramente vivenciável, é criar um tópos negativo. Sem limites, sem arquitetura, sem moeda, sem as diferenças habituais entre ricos e pobres, homens e mulheres, a Stoa quer, pela inviabilidade prática da teoria, conscientizar o homem histórico de sua própria indigência, de suas falsas instituições, dos sufocantes limites e injustas diferenças que a edificação das cidades carrega na história" (GAZOLLA, 1999, p. 72).

12. Neste projeto há uma contradição insuperável que se revela quando confrontado com outra passagem de Diógenes Laércio (DIOGÈNE LAËRCE, Vies et opinions des philosophes, VII, 121, SCHUHL, 2002, p. 54) segundo a qual Zenão teria afirmado na República que os homens deveriam se casar, o que não parece possivel em um Estado encorajador da promiscuidade, ainda que informado por nobres propósitos. Schofield acredita tratar-se de um erro - talvez voluntário - do doxógrafo, que já demonstrou não ser muito confiável ao cometer vários equívocos ao descrever alguns aspectos das obras de Platão e de Aristóteles (SCHOFIELD, 1999, pp. 126-127). Contudo, lembremo-nos que a defesa do casamento constitui uma opinião comum no seio do estoicismo mais convencional, tendo sido recolhida e confirmada por Cícero, para quem o sábio se ocupa dos negócios públicos, casase e tem filhos, cumprindo assim a lei da natureza. (CICÉRON, Des fins des biens et des maux, III, XX, 68, SCHUHL, 2002, p. 287). ReydamsSchils dedica boa parte do seu estudo à análise do casamento no estoicismo, concluindo que se trata de um dever do sábio comprometido com a comunidade, da qual participa por força de um imperativo da razão (REYDAMSSCHILS, 2005, pp. 143-176). 
13. A homossexualidade de Zenão é tida como certa por Diógenes

Laércio, que ainda nos informa que o filósofo se utilizava vez por outra de mulheres para que não o julgassem hostil ao sexo feminino (DIOGÈNE LAËRCE, Vies et opinion des philosophes, VII, 13, SCHUHL, 2002, p. 21). Entretanto, ao contrário de Epicuro, Zenão não se rende a qualquer sensualismo. Em certa ocasião ele afirmou que os mestres que passam tempo demais com os efebos são tão insensatos quanto estes (DIOGÈNE LAËRCE, Vies et opinions des philosophes, VII, 23, SCHUHL, 2002, p. 23). Na verdade, os estoicos idealizavam o amor ao concebê-lo como desejo de amizade e não de união carnal. Por isso diziam que eclosão da beleza era a flor da virtude (DIOGÈNE LAËRCE, Vies et opinions des philosophes, VII, 130, SCHUHL, 2002, p. 57]). Sobre o tema, cf. STEPHENS, 1996, pp. 193-210.

14. Cf., v.g., PLATÃO, 2001, V

453c-e, pp. 216-217, a respeito das diferenças entre homens e mulheres que dão lugar a tribuições de funções diversas cada gênero na república, apesa e Platão entender que ambos são guais em termos de racionalidade, sendo que as mulheres também podem ser guardiãs e filósofas (PLATÃ0, 2001，V, 456a, pp. 220

221). Contudo, “[...] as qualidade naturais estão distribuídas de modo semelhante entre ambo os sexos, e a mulher participa de todas as atividades, de acordo com a natureza, e o homem também, conquanto em todas elas a mulher seja mais débil do que o homem" (PLATÃ0, 2001,

V, 455d-e, p. 220). 0 tratamento dispensado por Platão às mulhere em A república nos parece dúbio obscuro. Em algumas passagens, louva-as, em outras (v.g., PLATÃo, 2001, V, 469d-e, p. 245) compara-

as a pessoas que têm pouco entendimento e mesmo aos cães.

15. “[...] se a filósofos eminentes se deparou a necessidade de se ocuparem do governo, na imensidão do tempo passado, ou se ela actualmente existe em qualquer país bárbaro, situado longe das nossas vistas, ou se vier algum dia a existir, nós estamos dispostos a sustentar, a esse respeito, que existiu a dita constituição, que existe e que existirá, quando essa Musa [a da Filosofia] se assenhorear do Estado, embora também da laços sociais muito fortes entre os seus cidadãos, o que não teria sentido em um Estado destinado a permanecer no plano da utopia. Sem dúvida, Zenão se opunha aos convencionalismos legais, dentre os quais se contam aqueles que regulam o casamento (ARNOLD, 1971, p. 277). Ao postular que o matrimônio não existe per naturam, nada mais lógico do que admitir a quebra das barreiras sociais, econômicas e políticas por meio da miscigenação indiferenciada dos cidadãos, todos iguais em sabedoria, inclusive as mulheres.

0 segundo texto citado por Schofield em abonamento à sua tese é o fragmento 561c do oitavo livro do Deipnosophists de Ateneu. Ei-lo: "Pontianus said that Zeno of Citium took love to be a god who brings about friendship and freedom, and again concord, but nothing else. That is why in the Republic he said that Love is a god, there as a helper in furthering the safety of the city" (apud SCHOFIELD, 1999, p. 26). Segundo a leitura de Schofield, a república de Zenão seria algo como uma "cidade do Amor" na qual Eros manteria os vínculos sociais estreitamente unidos de modo a originar e a preservar a virtude entre os cidadãos. Arnim recolhe um fragmento de Zenão no qual ele diz que o Amor é o deus da sua república, sendo responsável pela manutenção da segurança na cidade (ARNIM, 1968, I, 263). Arnold entende que o amor e a amizade surgiriam naturalmente entre os sábios da cidade perfeita de Zenão, pois eles partilham a mesma razão universal que comanda o universo (ARNOLD, 1971, p. 275). Para fundamentar a sua proposta, Zenão teria se baseado na figura histórica de Esparta, pólis na qual a homossexualidade cumpria funções políticas, servindo aos propósitos da rígida educação militar graças à qual os jovens lacedemônios se submetiam à autoridade adulta de forma absoluta. Schofield cita também o Pavilhão Sagrado de Tebas, guarnição militar de elite considerada invencível na Antiguidade. Ora, o Pavilhão era formado exclusivamente por duplas de amantes. Acreditava-se que os enamorados lutariam de modo mais encarniçado para assim preservarem a vida um do outro (SCHOFIELD, 1999, pp. 35-42).

Ainda segundo Schofield, a ideia de sublimidade do amor homossexual ${ }^{13}$ entre os gregos - que não se resolveria como paixão negativa, mas levaria à celebração da amizade e da concórdia entre os cidadãos da república -, encontraria base doxográfica em certa passagem de Diógenes Laércio. Nela lemos que os sábios amam a beleza dos efebos porque a veem como um reflexo da virtude (DIOGÈNE LAËRCE, Vies et opinions des philosophes, VII, 129, SCHUHL, 2002, p. 57), tópico que se refere à antiga associação que o pensamento grego estabeleceu entre Beleza e Verdade. Mas Zenão não despreza as mulheres. Na linha de Platão ${ }^{14}$ e contrariando Aristóteles, ele entende que elas podem cumprir funções políticas tão bem quanto os homens, motivo pelo qual Zenão não diferencia os dois gêneros e exige que ambos usem vestimentas iguais em sua república. De fato, o pensamento estoico se concentra na essência racional do ser humano, igual em machos e em fêmeas da espécie, presente tanto em cidadãos livres quanto em escravos, traço igualitarista que será desenvolvido posteriormente em Roma, onde a mulher exerceu papéis políticos muito mais importantes do que na Grécia (FAVEZ, 1933, pp. 1-8 e 1938, pp. 335-345). 0 que diferencia realmente as pessoas é a virtude e não o gênero. Há mulheres virtuosas e viciosas, bem como homens bons e maus. Cleantes escreveu um livro, hoje perdido, cujo título demonstra o que pensavam os estoicos sobre as mulheres: Da virtude como idêntica entre os homens e as mulheres (DIOGÈNE LAËRCE, Vies et opinions des philosophes, VII, 175, SCHUHL, 2002, p. 73). A mulher pode e deve participar da república zenoniana na mesma medida que o homem. Em tal hipótese será ainda o amor heterossexual ou homossexual - que garantirá a sua perfeita inclusão funcional no Estado (SCHOFIELD, 1999, pp. 43-46).

Com base nestes numerosos argumentos, Schofield pretende convencer-nos de que a república de Zenão nada tem de utópica, tendo sido pensada como forma de organização política realizável no tempo e no espaço, ao contrário da república de Platão, perdida em seu idealismo. Diferentemente do de Platão, o Estado de Zenão não exige quaisquer condições especiais, materiais ou técnicas para se concretizar, bastando apenas que os cidadãos se decidam, como em um passe de mágica, a serem virtuosos. Dentro da melhor tradição estoica, requer-se apenas uma mudança 
interior no indivíduo para que a sociedade perfeita, exterior ao ser, passe a existir:

In Zeno's city there is no legislation, no eugenic programe, no stratification of society or military organisation, and so no need for the absolute powers of a philosopher ruler - a ruler likely to be found only in some time or at some place far distant from now or here. All that is necessary for the realisation of Zeno's vision is that people begin to exercise their capacity for virtue: a strenuous undertaking, but something wholly within their own power right here and now. To put the point more crisply, Zeno's message in the Republic is perhaps best construed as an injunction: make your own city, with your friends, now, wherever you happen to live (SCHOFIELD, 1999, pp. 148-149).

Para Schofield, de certo modo a república de Zenão inclusive já existia na realidade histórica grega, sendo formada por ele e seus discípulos estoicos, amigos ligados por vínculos de concórdia e harmonia cujas ações virtuosas pretendiam se guiar pela influência racional do lógos (SCHOFIELD, 1999, pp. 150-151). Mas se a república de Zenão foi por ele mesmo definida como uma cidade de sábios, poderíamos objetar que a comunidade reunida em torno da Stoá Poikíle não pode ser entendida como a prefiguração da cidade ideal, eis que não era integrada por sábios. Certamente motivados pela modéstia natural à seita, os estoicos jamais se julgaram sábios e apenas com muitas reservas apontaram alguns personagens que talvez pudessem ser tidos nessa alta conta, tais como Sócrates e Diógenes, o cínico. Sêneca compara o sábio à fênix: ambos surgem, com sorte, de quinhentos em quinhentos anos, o que não the parece nada notável, dado que as coisas comuns são produzidas pela Fortuna aos borbotões, enquanto as excelentes se recomendam pela sua própria raridade (SÉNECA, 2006, XLII, 1, p. 113). Schofield rebate este argumento sustentando que o tópico relativo à inexistência do sábio possivelmente foi desenvolvido no contexto de polêmicas mantidas com os epicureus bem depois da redação da República de Zenão. Com efeito, os epicuristas se julgavam os únicos homens verdadeiramente sábios e os estoicos buscavam maneiras de se contrapor a tal presunção (SCHOFIELD, 1999, pp. 152-153). 0 citado paradoxo seria apenas uma estratégia do Pórtico para marcar sua posição contrária aos delírios vaidosos dos seguidores de Epicuro, não representando nenhum entrave funcional à concretização da república de virtuosos propugnada por Zenão.

Em síntese, para Schofield a República de Zenão não se revela como obra de inspiração cínica. Trata-se antes de um texto que se encaixa na tradição fundada pel'A república de Platão, proposta político-jurídica paradigmática à qual o fundador do estoicismo teria pretendido oferecer uma vigorosa objeção. Erskine chega à mesma conclusão (ERSKINE, 1990, p. 15). Diante da sociedade hierarquizada e dividida em classes pensada por Platão, Zenão teria oposto uma comunidade sem classes e sem hierarquia social na qual todos são igualmente sábios (ERSKINE, 1990, pp. 20-21) e não há propriamente um governo, algo desnecessário quando os cidadãos são todos amigos (ERSKINE, 1990, p. 26). Ao contrário, em um Estado de desiguais o superior deve comandar o inferior, impondo-lhe a observância da razão (PLATÃ0, 2001, IX, 590c-d, p. 444). 0 problema da harmonia política (homonoia) vivenciado por Platão nos anos de decadência de Atenas e aprofundado dramaticamente no contexto do helenismo alexandrino, quando diversas perturbações sociais acabaram por destruir o regime de liberdades da pólis grega, encontra assim duas soluções distintas: na obra platônica mantém-se o organismo político saudável mediante a subordinação das classes inferiores às superiores (PLATÃ0, 2001, IV, 431a-e, pp. 181-183). Por isso A República de Platão é uma justificação da aristocracia.

A resposta dada por Zenão ao referido problema parece-nos mais radical e, surpreendentemente, menos realista do que a do "idealista" Platão: suprime-se a noção de classe, bem como os objetos sobre os quais se funda a hierarquia causadora de distúrbios. Tendo em vista que a alma estoica é una e que a faculdade racional (hegemonikon) estende os seus tentáculos por todo o corpo, não é possível a Zenão adotar a solução platônica. Na alma-corpo estoica não há subordinação entre as partes. Não existem sequer partes, apenas um todo igualmente racional, imagem que, transplantada para o terreno nossa parte se concorde que é difícil" (PLATÃ0, 2001, VI, 499c-d, p. 292). Morrison aduz que Platão tinha plena ciência da irrealizabilidade de sua cidade ideal. Cf. MORRISON, 2006, p. 47. Tal leitura parece se coadunar com a conclusão do Livro IX: "Refereste à cidade que edificámos há pouco na nossa exposição, àquela que está fundada só em palavras, pois creio bem que não se encontra em parte alguma da terra. - Mas talvez haja um modelo no céu, para quem quiser contemplá-la e, contemplando-a fundar uma para si mesmo. De resto, nada importa que a cidade exista em qualquer lugar, ou venha a existir, porquanto é pelas suas normas, e pelas de mais nenhuma outra, que ele [o legislador] pautará o seu comportamento" (PLATÃ0, 2001, IX, 592a-b, p. 447). 
da política, explicará a preferência dos estoicos gregos pela democracia, forma de exercício do poder em que não há superiores ou inferiores, mas apenas iguais (ERSKINE, 1990, p. 71). A proibição da cunhagem de moedas e a propriedade comunitária - até mesmo das mulheres - são expedientes que objetivam garantir a igualdade e a harmonia na república zenoniana. Discordando de Platão, Zenão não pretende alcançar a paz social subordinando as classes inferiores às superiores; ele não é um aristocrata, mas um igualitarista para quem não há classes. Alguns ecos da posição zenoniana parecem ter repercutido no estoicismo imperial de Epicteto, que citando a Odisseia de Homero (XIV, v. 56 et seq.) nos lembra que não podemos tratar estrangeiros e mendigos com desprezo, pois todos vêm de Zeus (ÉPICTÈTE, Entretiens, IV, XI, 4, SCHUHL, 2002, p. 984).

Contudo, Zenão é antes de tudo um pensador grego. Seu igualitarismo não deve ser confundido com um comunismo vulgar como o de Marx. A condição para que todos sejam iguais na pólis zenoniana é a sabedoria. A república de Zenão consiste em uma comunidade de sábios autorreguladora na qual os tolos são tratados como inimigos, postura muito mais elitista do que a platônica, com o que desconfiamos da tese democrática de Erskine. Ele mesmo admite que se há alguma igualdade na república zenoniana, tal se dá pela ação da virtude e não pela riqueza, nascimento ou classe social (ERSKINE, 1990, p. 72). Ora, sendo certo que pouquíssimos homens são virtuosos, Zenão acaba fundando uma república ainda mais elitista e limitadora do que a platônica. De fato, Platão resolve o problema da diferença de classes subordinando as inferiores às superiores, garantido assim que ambas possam conviver no mesmo Estado. Zenão sequer suporta a presença dos tolos. Ele simplesmente elimina do horizonte político os seres humanos considerados inferiores, pois é impossível para o sábio conviver com o não-sábio.

Parece-nos revelador notar que as soluções políticas para o problema da harmonia social pensadas por Platão e Zenão encontram paralelo nas suas respectivas Psicologias (ERSKINE, 1990, p. 31). Em Platão a razão deve dominar os desejos irracionais para que o homem justo alcance o equilíbrio da alma (PLATÃ0, 2001, IV, 431b, p. 181). Da mesma maneira, o equilíbrio político é atingido quando os sábios, únicos conhecedores da verdadeira razão, governam as demais classes. Por seu turno, Zenão e os estoicos recomendam a extinção das paixões para que apenas a razão presida a alma. Conforme demonstramos em outro trabalho (MATOS, 2009, pp. 154-164), os estoicos não acreditam ser possível controlar ou moderar a irracionalidade como sugeria Aristóteles, motivo bastante para que ela seja extirpada da alma una concebida pela Stoá. Assim como o sábio anula as paixões de seu quadro psíquico, analogamente os tolos devem ser impedidos de viver no Estado zenoniano. À uma alma completamente racional corresponde um Estado integralmente composto por sábios, com o que se garante a completa aniquilação do alógos. Compreendemos assim porque a qualificação de "democrático" não se adapta bem ao pensamento político dos estoicos gregos.

Adotando por modelo o amor cívico-homossexual espartano, a república de Zenão conformaria uma provocação irônica ao aspecto marcadamente ateniense e estratificado da república de Platão. A Politeia de Zenão seria então uma resposta consciente ao projeto político contido em $A$ república (ERSKINE, 1990, p. 30). Zenão teria levado a sério os princípios de Licurgo, célebre legislador espartano que, segundo Plutarco, comparava as cidades aos indivíduos, sustentando que em ambos a felicidade somente pode ser atingida mediante a virtude e a harmonia interna (ERSKINE, 1990, p. 19). Tal ideal teria levado Zenão a propor uma pólis integrada por homens iguais e moralmente perfeitos, vivendo em uma comunidade sem contendas e distante da realidade caótica da pólis helênica, mergulhada na revolta social e nas lutas de classe rapidamente degeneradas em duradouras guerras civis que levariam os gregos a perderem definitivamente as suas liberdades políticas, primeiro para a Macedônia e depois para Roma. Em um nível mais profundo de leitura, o texto de Zenão representaria um diálogo entre Licurgo (Zenão/Esparta) e Sócrates (Platão/Atenas) sobre a melhor forma de governo. Assim como os espartanos, Zenão teria feito do amor um elemento essencial para a estruturação do seu Estado, ainda 
que se trate de uma forma radicalmente sublimada de amor, homossexual por excelência e não sensual, mas que, todavia, não exclui a heterossexualidade (SCHOFIELD, 1999, p. 56).

Apesar do vigor da argumentação de Schofield, discordamos de sua posição, que se fundamenta em interpretações mais ou menos livres de fragmentos isolados e desconsidera várias passagens doxográficas incômodas para a sua hipótese, em especial aquela na qual Diógenes Laércio explica que na cidade ideal de Zenão todos os não-sábios devem ser tratados como escravos e inimigos (DIOGÈNE LAËRCE, Vies et opinions des philosophes, VII, 32-33, SCHUHL, 2002, pp. 27-28), o que dificilmente se coaduna com a ideia de um Estado regido por Eros e garantido pela amizade e a concórdia mantidas entre os cidadãos. Também não podemos olvidar que Esparta - modelo histórico do "Estado erotizado" que Zenão teria em mente - era beligerante e militarista, o que entra em choque com a filosofia pacifista que desde sempre caracterizou o Pórtico. Além disso, diferentemente da cidade de Platão, a pólis de Zenão não conta com programas eugênicos para selecionar os melhores guerreiros e os mais sábios entre os sábios (ERSKINE, 1990, pp. 32-33). Sem dúvida, nada disso é necessário em um Estado igualitarista e pacifista que jamais se envolve em guerras. Contudo, como poderia a pólis zenoniana sobreviver em um mundo no qual as demais cidades, comandadas por tolos, estariam prontas para destruí-la por meio da guerra? Erskine entende que eventuais relações - pacíficas ou hostis - da república de Zenão com cidades reais não devem ser consideradas, eis que a pólis zenoniana deve ser compreendida de maneira isolada, como um experimento laboratorial cuidadosamente controlado e apartado da realidade. ${ }^{16}$

Ainda que a interpretação de Erskine pareça interessante, se a adotarmos teremos que abrir mão de qualquer possibilidade de implementação da república zenoniana, transformando-a, assim como a república de Platão, em um Estado ideal fora da história. Tal parece contradizer os objetivos de Zenão, que, de acordo com Schofield, queria apresentar um plano político apto a se concretizar no mundo real. Inevitável, portanto, a crítica quanto ao pacifismo do Estado zenoniano, incapaz de conviver com outras cidades no plano fenomênico. A república de Zenão é tão exigente - e tão irrealizável - quanto o ideal-tipo do sábio perfeito integralmente racional e incapaz de praticar atos viciosos.

Parece-nos que a compreensão mais plausível da República zenoniana é aquela que Schofield chama de "revisionista", informada pelo cinismo que impregnou o estoicismo grego e o jovem Zenão de Cício, discípulo de Crates. Ainda que a República de Zenão não tenha sido escrita durante a sua juventude, os traços dos ensinamentos cínicos jamais foram apagados da sua mente. Mais do que idealista (Platão) ou realista (Schofield), a intenção de Zenão é crítica e, como tal, muito próxima da atitude central do cinismo. Por um lado, a Politeia consiste em um vigoroso ataque dirigido ao idealismo platônico; por outro, trata-se de um libelo contra o despotismo de Demétrio de Falera, tirano em Atenas de 317 a 307 a.C. Sem dúvida Zenão pretendia que a sua obra gerasse reflexos práticos e concretos, mas não julgamos que ele tenha proposto um plano a ser aplicado tout court à realidade. Ao contrário de muitos dos nossos burocratas contemporâneos, parece que Zenão não imaginava ser possivel conter o mundo nos limites de algumas folhas de papel mágicas chamadas de "projetos de reestruturação", "planos de gestão" ou algo assim. Tal soaria por demais naïf para um estoico. Os propósitos de Zenão são crítico-universais e, por isso mesmo, filosóficos. 0 problema que inspirou a redação de sua Politeia decorreu da decadente situação política grega, mas não se limitou apenas a tal contexto. 0 Estado zenoniano não está localizado em nenhum tempo específico e em nenhum espaço determinado porque serve para todo tempo e para qualquer espaço. Zenão espera influir na realidade política - em qualquer tempo e lugar - nos apresentando um Estado ideal para que percebamos quão longe estamos dele (ERSKINE, 1990, p. 41).

\section{A virada tradicionalista de Cícero}

0 Estado ciceroniano é muito mais convencional do que o sonho igualitarista zenoniano. Apesar de não se tratar de um texto escrito segundo os ditames estoicos, não podemos deixar de fazer bre-
16. "Zeno is not concerned with placing this society in a historical or geographical context, but with examining it in isolation. The assumption is made that there are no other states co-existing with the ideal state.[...] What Zeno put forward in the Politeia was not a description of a world state or community as some have supposed but a philosophical inquiry. It is an ideal and natural society not located in any particular time or place. It is not limited to a single polis, but nor are its limits clearly defined, because this is irrelevant to the purpose of the inquiry" (ERSKINE, 1990, p. 23). 
17. Cf. ARISTÓTELES, 2001 VIII, 1160a-1161b, pp. 164-167, passagem na qual o estagirita nos apresenta a sua tradicional divisão das formas de governo de acordo com a quantidade dos que governam - um, alguns ou todos - e o interesse público ou privado que as qualifica em formas puras (monarquia, aristocracia e timocracia) ou degeneradas (tirania, oligarquia e democracia). 0 tema foi desenvolvido por Aristóteles com mais detalhes no livro V da Política. A breve obra de Saldanha sobre o assunto é preciosa: SALDANHA, 1960.

18. A ideia de um "Estado misto" não foi gestada por Cícero tendo sido antes apresentada por Tucídides, Dicearco, Platão (As leis, III, 676 et seq. IV, 712 et seq e VI, 369 et seq.), Isócrates, Aristóteles (1998, 1294b, 15 et seq.), Panécio e Políbio. Cf. FASSÒ 2001, p. 80 e TATAKIS, 1931, p. 214. Apesar de não citar nomes específicos, Diógenes Laércio nos informa que para os estoicos em geral o melhor governo é uma mistura cujos elementos são democracia, a monarquia e a aristocracia. Cf. DIOGĖNE LAËRCE, Vies et opinions des philosophes, VII, 131, SCHUHL, 2002, p. 58).

19. “Desses três sistemas primitivos, creio que o melhor é, sem disputa, a monarquia; ma ela mesma é sempre inferior à forma política que resultaria da combinação das três. Com efeito, prefiro, no Estado, um poder eminente e real, que dê algo à influência dos grandes e algo também à vontade da multidão

É essa uma constituição que apresenta, antes de mais nada, um grande caráter de igualdade, necessário aos povos livres e, bem assim, condições de estabilidade e firmeza. Os primeiros elementos, de que falei antes, alteram-se

facilmente e caem no exagero do extremo oposto. Assim, ao rei sucede o tirano; aos aristocratas, a oligarquia facciosa; ao povo, a turb anárquica, substituindo-se desse modo umas perturbações a outras. Ao contrário, nessa combinação de um governo em que se amalgaman os outros três, não acontece facilmente semelhante coisa sem que os chefes do Estado se deixem arrastar pelo vício; porque não pode haver pretexto de revolução num Estado que, conforme cada um com os seus direitos, não vê sob seus pés aberto o abismo" (CÍCERO, 1973, I, XLV, p. 160) ve referência ao tratado Da república de Cícero (n. 106 a.C. - m. 43 a.C.), já que ele espelha algumas das concepções correntes no século I a.C. sobre Direito e Política. Diferentemente dos seus ilustres antecessores - Platão, Zenão e Crisipo -, Cícero não tencionou descrever uma república ideal. Seu objetivo era apenas refletir sobre a melhor forma de governo, tópico favorito da intelectualidade greco-romana, em especial Aristóteles, que delineou a primeira teoria geral das formas de governo. ${ }^{17}$

0 tratado de Cícero mostra-se desconexo e pouco original, afastando-se bastante das fantasias propostas por Zenão. No livro I, a par de tratar de variadíssimos temas, Cícero define a república como coisa do povo, “[...] considerando tal, não todos os homens de qualquer modo congregados, mas a reunião que tem seu fundamento no consentimento jurídico e na utilidade comum" (CÍCERO, 1973, I, XXV, p. 155). A melhor república seria aquela que congregasse as vantagens das clássicas formas puras de governo: ${ }^{18}$ a afeição recíproca entre governantes e governados característica da Monarquia, a sabedoria própria da Aristocracia e a liberdade que viceja apenas na Democracia. Isoladas, as três formas de governo não seriam suficientemente boas, embora Cícero entenda que a melhor seria a Monarquia e a pior a Democracia, pois naquela, ainda que degenerada em Tirania, suportamos o arbítrio de um único homem, enquanto nesta, se corrompida, impõe-se a vontade caótica da massa.

0 pensador romano explica ainda que as formas de governo são instáveis (CÍCER0, 1973, I, XLIV, p. 160) e se sucedem ciclicamente no tempo, de modo que a Monarquia degradada em Tirania acaba sendo substituída pela Aristocracia; mais tarde, tornada Oligarquia, esta sucumbe à revolução popular que forçosamente inaugura o governo democrático. Por sua vez, este não tarda a se corromper e dá lugar à desordem do vulgo. Impõe-se então uma vez mais a centralização do poder nas mãos de um só, com o que o ciclo se reinicia (CÍCERO, 1973, I, XXIX-XXXV, pp. 155-157). A única maneira de evitarmos essa funesta recorrência seria a amálgama das três formas puras, que daria lugar a uma república compósita ${ }^{19}$ em que o autocontrole surgiria não da tripartição das funções do poder, ${ }^{20}$ mas sim das relações travadas entre a quantidade e a qualidade, ou seja, entre a plebe e a nobreza. Mediada por instituições republicanas e por um ordenamento jurídico capaz de garantir a cada qual os seus direitos segundo determinadas circunstâncias (CICÉRON, 1959, III, VII, 15-17, pp. 89-90), a república mista manteria incólumes os dois fundamentos básicos do bom governo: a concórdia e o espírito de equidade (CÍCERO, 2000, II, 78, p. 109).

Ainda que a argumentação de Cícero não envolva grandes novidades, parece-nos interessante notar como ele encaminha a discussão teórica para o domínio da realidade romana do século I. a.C. 0 momento histórico que Cícero viveu parecia ser um daqueles em que graves mudanças se avizinhavam. Estando a aristocracia e o povo descontrolados pela cobiça e envolvidos em fratricidas guerras civis, impunha-se a necessidade de ordem que somente um verdadeiro monarca poderia conceber e manter. Foi assim que, talvez inadvertidamente, um republicano convicto como Cícero acabou por legitimar o emergente Império de Augusto. 0 livro II de Da republica confirma esta assertiva, pois nele Cícero examina a história de Roma para demonstrar a aplicabilidade de sua teoria cíclica do poder. Sob os auspícios de bons reis, Roma prosperou. No entanto, bastou 0 reinado tirânico de Tarquínio para que os patrícios concretizassem uma revolução aristocrática que, com o tempo, deu lugar ao governo democrático, especialmente depois da expulsão dos decênviros que redigiram as duas últimas das XII Tábuas. Devido à imensa corrupção e à degradação moral que caracterizava o último século da República, Cícero antevia o surgimento de uma nova monarquia romana e se lamentava: "Nossos vícios, e não outra causa, fizeram que, conservando o nome de República, a tenhamos já perdido por completo" (CÍCERO, 1973, V, I, p. 183).

\section{Sêneca e a justificação do Império}

Inevitável, portanto, o surgimento de uma nova teoria do poder - inclusive de base estoica - na fase imperial. Tal se deveu a Sêneca (n. 4 a.C. - m. 65 d.C.). Conforme demonstra Vizentin, ${ }^{21}$ o cordobês assentou as bases de um novo tipo de Estado e de 
governo no De clementia, ${ }^{22}$ tratado dirigido a Nero, seu jovem pupilo que então acabava de assumir as rédeas do Império Romano depois da suspeita morte de Cláudio.

Sêneca já não deplora, como Cícero, o fim da República, visto que a realidade imperial era patente e irreversível. Ao contrário, parecia-lhe necessário superar a Constituição dúbia legada por Augusto (VIZENTIN, 2005, p. 46) e que garantia uma ilusória sobrevida às instituições republicanas. Caberia ao Imperador assumir o seu verdadeiro papel de rei, embora tudo devesse fazer para se afastar da tirania. Tal seria factível se o Princeps soubesse utilizar a clemência, virtude sem a qual não é possível governar e que, segundo Sêneca, é tida como a mais excelente de todas tanto por estoicos quanto por epicuristas, (SÉNÈQUE, 1961, III, I [I, 3], 2, pp. 15-16), o que não é verdade no que se relaciona à Stoá.

0 Imperador precisa utilizar a clemência com racionalidade para aplicar equitativamente as leis e garantir a sua própria perpetuação no poder, eis que, sendo clemente, o Príncipe perdoa os seus inimigos e os transforma em aliados (VIZENTIN, 2005, p. 112), tal como antes habilmente agira Júlio César (DINIZ, 2006, p. 57 e 66). Com efeito, a segurança do governante funda-se no bem-estar dos governados (SÉNÈQUE, 1961, III, XVII [I, 19], 5, p. 40), razão pela qual o líder político piedoso não precisa de cidadelas e de muralhas fortificadas para defendê-lo, mas apenas do amor do povo, fortaleza inexpugnável (SÉNÈQUE, 1961, III, XVII [I, 19], 6, p. 40). Na verdade, o tópico argumentativo referente ao "bom soberano" já era antigo na filosofia política greco-romana. Bem antes de Sêneca, Cícero se perguntava se era melhor para o governante ser amado ou odiado (CÍCERO, 2000, II, 23, p. 85), concluindo que os que são temidos somente podem temer aqueles que os temem (CÍCERO, 2000, II, 24-25, p. 86), fato que evidencia o grande poder da benevolência e a fraqueza do medo quando se trata de manter o poder (CÍCERO, 2000, II, 29, p. 88). Conhecemos a fortuna argumentativa que tal topus renderá nas mãos de Maquiavel no alvorecer da Modernidade, ainda que em sentido contrário ao pensamento de Cícero e de Sêneca.
De acordo com Sêneca, os grandes homens devem se reger por uma moral igualmente elevada (magnam fortunam magnus animus decet) (SÉNÈQUE, 1961, III, III [I, 5], 5, p. 19). Ora, tal exigência se coaduna com a tradição estoica segundo a qual só o homem capaz de se autogovernar é apto para gerir o Estado (SÉNECA, 2006, XL, 4, pp. 108-109). Se o trono for ocupado por indivíduos sábios, a monarquia certamente se revelará como a melhor forma de governo, tendo sido criada em termos perfeitos pela própria natureza (SÉNÈQUE, 1961, III, XVII [I, 19], 2, pp. 39-40). 0 ideal monárquico senequiano encontra no Princeps romano uma nova formulação, pois nele convergem abstratamente a figura do sábio estoico e o modelo do "primeiro dos cidadãos". Assim como os estoicos gregos justificaram durante algum tempo o poder dos diádocos, Sêneca transformou o despotismo imperial romano em uma espécie de monarquia eletiva, “[...] tornando, por meio do absolutismo moral do estoicismo, o absolutismo político aceitável, desde que a moralidade e a política se unam e que o rei virtuoso possa ser um diretor espiritual poderoso, modelo para seus governados" (VIZENTIN, 2005, p. 97). Se é verdade que o projeto político senequiano falhou diante da indigência moral de Nero, incapaz de se portar de acordo com as exigências éticas do estoicismo, não é menos certo que se realizou plenamente durante a dinastia dos Antoninos, em especial no Principado do rei-filósofo, Marco Aurélio, quando então o Império já estava assegurado e legitimado na mentalidade romana.

Na teoria do poder proposta por Sêneca, o Imperador comparece como elemento formal garantidor da unidade de um corpo social extremamente diversificado, espalhado por imensos territórios identificados com a cosmópolis, embora seja perceptível no De clementia uma constante tensão entre localismo e universalismo. Sêneca concebe a cidade de Roma como o centro nervoso do Império, motivo pelo qual a queda do Imperador significaria a dissolução de todos os laços que mantêm íntegro o Estado universal romano. Sem a unidade proporcionada pelo Princeps, a ordem imperial seria tragada de um só golpe por mais um período de guerras civis, o que deve ser evitado a qualquer custo (VIZENTIN, 2005, pp. 116117). Com base na percepção da natureza racional
20. Como queriam Aristóteles (1998, 1299a), Panécio (TATAKIS, 1931, p. 214) e, séculos depois, Locke e Montesquieu.

21. Além da obra de Vizentim, recomendamos 0 artigo de GONÇALVES, 1999, pp. 51-74.

22. Os números entre colchetes nas nossas citações do De clementia dizem respeito à ordenação tradicional da obra, tida por incompleta pela maioria dos estudiosos, uma vez que, dos três livros anunciados por Sêneca no proêmio, somente o primeiro parte do segundo teriam chegado até os nossos dias. A edição francesa de Préchac que utilizamos propõe uma nova estrutura para o tratado, de modo a reconstituir a sua integralidade mediante verdadeiras "cirurgias filológicas" capazes de reorganizar os trechos constantes do material conservado e apresentar os supostos três livros originais. Sobre o assunto, cf. VIZENTIN, 2005, pp. 87-90. 
do Império, Sêneca supera o pseudo-republicanismo mantido e incentivado por Augusto. No De clementia o Imperador já não representa o Estado; ele é o Estado ou, pelo menos, a sua parte mais importante - 0 caput - sem a qual toda a compacidade do Império se fragmentaria (VIZENTIN, 2005, p. 170). De maneira similar ao que ocorre nas colmeias, nas sociedades humanas a unidade do poder representaria uma regra natural absoluta; morto o rei, tudo se desorganiza e caminha para a guerra, campo no qual se forja o novo senhor supremo (SÉNÈQUE, 1961, III, XVII, [I, 19], 2, pp. 38-39). Foi o que ocorreu no fim da fase republicana durante as guerras civis que levaram Augusto a se tornar o dominus de Roma.

Segundo Sêneca, a "República” e o Imperador integram uma única realidade. Sendo este a personificação daquela, não podem ser separados sob pena de destruição da cosmópolis. 0 Estado possui a força, mas o seu dirigente é a cabeça capaz de pensá-la e direcioná-la (SÉNÈQUE, 1961, III, II, [I, 4], 1, pp. 17-18). Em várias passagens do tratado senequiano encontram-se referências explícitas ou implícitas ao caráter universal do Império Romano, que congregaria o populis urbibusque consensus em torno do amor dedicado ao Imperador (SÉNÈQUE, 1961, III, I [I, 3], 4, p. 16). Por sua vez, este não pode falar sem que a sua voz seja ouvida por todos os povos do orbe (SÉNÈQUE, 1961, III, VI [I, 8], 5, p. 23). 0 Príncipe clemente de Sêneca vela assim pelo mundo inteiro (cui curae sunt uniuersia) (SÉNÈQUE, 1961, III, XI [I, 13], 4, p. 32), inclusive pelas nações ainda não incorporadas a Roma e que, por isso mesmo, gozam de duvidosa liberdade (dubiae libertatis) ao longo das fronteiras imperiais (SÉNÈQUE, 1961, I, I [II, 1], 3, p. 7). Por isso o Império Romano desenvolveu um direito universal capaz de integrar todo o planeta em um único sistema jurídico fundado na majestade do lógos estoico.

\section{Os estoicismo e os direitos fundamentais modernos}

Hegel entende que devido à fuga da efetividade da liberdade - ou seja, da experiência real da liberdade -, a consciência estoica alcança somente o pensamento da independência. Apresentando-se como um para-si absoluto, a Stoá não procura se vincular a nenhum ser-aí e centra-se essencialmente na unidade do puro pensar. Processo semelhante se desenvolve no Estado de Direito liberal, no qual os direitos individuais abstratamente tratados não se conectam a um ser-aí ou ao Espírito Universal, “[...] mas antes ao puro Uno de sua efetividade abstrata ou a ele enquanto consciência-de-si geral" (HEGEL, 2002 , § 479, p. 332). Cabe ao indivíduo, assim como ao Estado de Direito, escapar dessa letargia inefetiva, o que só pode ser realizado mediante a concretização da liberdade. Tal proporcionará a superação dialética da divisão forma/conteúdo (HEGEL, 2002, § 480 , p. 333), tão apreciada no mundo jurídico. Pelo movimento que the é próprio, a liberdade precisa se apresentar no Estado de Direito enquanto forma e conteúdo. Em termos mais simples: a liberdade é forma, mas também é conteúdo, pois ao mesmo tempo em que garante a possibilidade de os cidadãos pensarem por si próprios e se expressarem (v.g., direito de livre crença, opinião e expressão), oferece e mantém as condições materiais necessárias a um convívio social justo, o que se dá pela positivação e realização de todos os direitos fundamentais, sejam eles civis, políticos, sociais, econômicos, coletivos ou difusos. Da mesma maneira que o indivíduo é levado não a abandonar a liberdade interior estoica, mas a aprofundá-la, integrá-la e superá-la, o Estado precisa, sem suprimir o respeito à liberdade de pensamento, expandir o significado da liberdade tendo em vista a realidade concreta, garantindo assim as suas outras expressões: liberdade de ir e vir, liberdade de escolha, liberdade de associação, liberdade de formação, liberdade de voto e até mesmo liberdade para se discordar das decisões do poder político, prerrogativa radicada na objeção de consciência, no direito de resistência e na desobediência civil.

Informados por esta perspectiva, julgamos adequado recordar com Loewenstein que o postulado segundo o qual existem direitos do indivíduo fora do Estado é caracteristicamente estoico (LOEWENSTEIN, 1986, p. 393 et seq.). Os demais filósofos da pólis grega e mesmo os políticos da República Romana, transpersonalistas como eram, não reconheciam nenhum âmbito de liberdade individual fora do organismo político, que englobava o indivíduo ao 
descrevê-lo enquanto parte do organismo social (RECASÉNS SICHES, 1970, p. 502). Tendo em vista a indissolubilidade do curriculum do Pórtico - Física, Lógica e Ética -, agora podemos entender a veemente negação estoica da Lógica aristotélica. $\mathrm{Na}$ Lógica de Aristóteles importa a forma geral, sendo o indivíduo um mero acidente ocasional (BRUN, 1986, p. 50). Ao contrário, para a Stoá o indivíduo é o sujeito lógico por excelência. Por seu turno, a Física estoica afirma que cada homem possui qualidades próprias. Embora elas não sejam irrepetíveis - lembremo-nos das conflagrações -, caracterizam e integram os seres, de sorte que, “[...] para os Estóicos, a individualidade é uma noção fundamental e constitutiva" (BRUN, 1986, p. 50). Tais concepções lógicas e físicas refletem-se na Ética e afastam o estoicismo do transpersonalismo. Foi o Pórtico que chamou a atenção do mundo pela primeira vez para a dignidade do ser humano não enquanto parte da sociedade, mas sim enquanto indivíduo essencialmente livre. Os estoicos viram na dissolução da pólis uma oportunidade para aprofundar a crítica das instituições sociais levada a efeito pelos sofistas e pelos cínicos e, desse modo, encontrar na dignidade do ser humano e na sua liberdade interior os liames que aproximam o homem individual e o homem universal. Diferentemente das demais filosofias antigas, o estoicismo não exige que o indivíduo seja imolado no altar do Estado, ${ }^{23}$ preferindo integrar ambas as realidades em um contexto cosmopolita capaz de realizar o que na Hélade foi apenas uma bela ilusão sonhada desde Platão até Alexandre, ou melhor, desde Heráclito até Demóstenes.

Antes de Hegel não há sistemas filosóficos da totalidade. A única exceção talvez seja o estoicismo, sempre disposto a assegurar, ainda que à força de paradoxos físicos, lógicos e éticos, que a unidade não se perca na pluralidade. 0 instrumento garantidor da peculiar identificação entre o uno e o múltiplo propugnada pela Stoá se revela historicamente na estrutura racional e universal do Direito Romano. Foi ao Direito Romano Clássico forjado em berço filosófico estoico que coube a alta tarefa de impedir a dissolução pura e simples do indivíduo na postulação de destinos sociais transcendentes (RODRIGUES, 2005, p. 17) e atemporais, como ocorrera na Grécia e nos primeiros séculos de Roma. Segundo Tatakis, ao insistir na necessidade de aperfeiçoamento moral, os estoicos introduziram uma novidade na mentalidade romana: a mirada para o interior, o que pôde converter os romanos em indivíduos humanizados. Com efeito, Panécio foi um dos primeiros humanistas do pensamento ocidental (LIMA VAZ, 1999, p. 160). A partir do século II a.C., quando o individualismo particularista explode na República e já começa a engendrar os imperadores, o indivíduo humanizado pelo estoicismo será a única esperança da humanidade (TATAKIS, 1931, p. 14) e do Império Universal: “C'est la pensée Stoïcienne par conséquent, qui, plus que toute autre, dévoila au Romain le chemin qui menait à l'humanisme et à la civilisation" (TATAKIS, 1931, p. 16). Nesse sentido, Panécio cumpriu um papel singular em Roma ao transformar a rígida moralidade cósmica dos fundadores gregos em uma moral social mais palatável, dirigida especialmente aos patrícios romanos, que em um espaço de tempo demasiado curto tinham dizimado de maneira selvagem Cartago e Corinto (TATAKIS, 1931, p. 200). Antevendo os tempos de embrutecimento e de submissão que se avizinhavam da urbs, Panécio soube seduzir os melhores romanos - v.g., Cipião e Cícero - com uma doutrina estoica renovada, capaz de infundir-lhes a racionalidade necessária ao papel civilizatório que a História Universal thes reservara.

Mediado pela ideia de liberdade interior estoica posteriormente refundida pelo cristianismo medieval, o indivíduo titular de direitos - entre os quais o de pensar livremente - aparece pela primeira vez no cenário político-jurídico ocidental. A partir daí a consequência inevitável da liberdade de pensamento será a capacidade de expressar-se - “Venera o poder de opinar", aconselha Marco Aurélio (MARCO AURÉLI0, 1973, III, 9, p. 281) - e de dissentir do Estado quando ele estiver dominado pelo irracional (alógos). Aí se insere o direito, mecanismo racional cuja missão consiste em fazer refletir a ordem cósmica da recta ratio na esfera das relações sociais. De fato, o que é o direito senão uma garantia de racionalidade oponível até mesmo ao Estado, esse senhor sem senhores? Eis o sentido profundo do Estado de Direito intuído pela jurística romana e levado a termo pelos revolucionários franceses de
24. Em sentido contrário, $\mathrm{cf}$ VEYNE, 1996, p. 61. De acordo com a sua leitura de certos axiomas estoicos, Veyne entende que o sacrifício em prol do cosmos constitui uma obrigação exigível de todos os homens. Mas ele acaba por reconhecer que o estoicismo é uma "receita de felicidade pessoal" e por isso mesmo se dirige especificamente ao indivíduo e não ao corpo social como um todo (VEYNE, 1996, pp. 97-111). 
1789. Nele as normas jurídicas são produzidas para possibilitar a supremacia do lógos, sem o que a irracionalidade proporcionada pelas paixões privadas e pelos vícios públicos corrói a estrutura ético-jurídica fundamental, que é exatamente a justiça, dimensão ideal - porém vivenciável fenomenicamente - sem a qual não há igualdade e nem liberdade.

\section{Referências Bibliográficas}

\subsection{Fontes primárias:}

ARISTÓTELES. Ética a Nicômacos. Trad., introdução e notas Mário da Gama Kury. 4. ed. Brasília: Universidade de Brasília, 2001.

ARISTÓTELES. Política. Ed. bilíngue grego/português. Nota prévia de João Bettencourt da Câmara. Prefácio e revisão literária de Raul M. Rosado Fernandes. Introdução e revisão científica de Mendo Castro Henriques. Trad. e notas António Campelo Amaral e Carlos de Carvalho Gomes. Índice de conceitos e nomes de Manuel Silvestre. Lisboa: Vega, 1998.

ARNIM, Johannes von (org.). Stoicorum veterum fragmenta. 4 vols. Stuttgart: Teubner, 1968.

CÍCERO, Marco Túlio. Da república. Trad. Amador Cisneiros. In: Os pensadores. Vol. V. São Paulo: Abril Cultural, 1973.

CÍCERO. Dos deveres (de officiis). Trad., introdução, notas, índice e glossário Carlos Humberto Gomes. Lisboa: Edições 70, 2000.

CÍCERO. Dos deveres (de officiis). Trad., introdução, notas, índice e glossário Carlos Humberto Gomes. Lisboa: Edições 70, 2000.

CICÉRON. Des fins des biens et de maux: livre III. Trad., rubriques et notes Émile Bréhier. Notice Victor Goldschmidt. In: SCHUHL, Pierre-Maxime (ed). Les stö̈ciens. Bibliothèque de la Pléiade. Paris: Gallimard, 2002.

CICÉRON. Premiers académiques: livre II. Trad. Émile Bréhier. Rev. Victor Goldschmidt. Rubriques, notice et notes Victor Goldschmidt. In: SCHUHL, Pierre-Maxime (ed). Les stoïciens. Bibliothèque de la Pléiade. Paris: Gallimard, 2002.

CICÉRON. Traité des lois. Trad. et texte établi par George de Plinval. Paris: Les Belles Lettres, 1959.

DIOGÈNE LAËRCE. Vies et opinions des philosophes: livre VII. Trad. Émile Bréhier. Rev. Victor Goldschmidt et P. Kucharski. Rubriques, notice et notes Victor Goldschmidt. In: SCHUHL, Pierre-Maxime (ed). Les stoïciens. Bibliothèque de la Pléiade. Paris: Gallimard, 2002.

DIÓGENES LAERCIO. Vidas de los filósofos ilustres. Trad., introducción y notas Carlos García Gual. Madrid: Alianza, 2007.

ÉPICTÈTE. Entretiens: livres I a IV. Trad. Émile Bréhier. Rev. P. Aubenque. Rubriques, notice et notes P. Aubenque. In: SCHUHL, Pierre-Maxime (ed). Les stoïciens. Bibliothèque de la Pléiade. Paris: Gallimard, 2002.
LONG, Anthony A.; SEDLEY, David N. (orgs.). The hellenistic philosophers. Vol. 1: Translations of the principal sources, with philosophical commentary. Cambridge: Cambridge University, 2006.

MARCO AURÉLIO. Meditações. Trad. Jaime Bruna. In: Os pensadores. Vol. V. São Paulo: Abril Cultural, 1973.

PLATÃO. A república. Trad., introdução e notas Maria Helena da Rocha Pereira. 9. ed. Lisboa: Calouste Gulbenkian, 2001.

SCHUHL, Pierre-Maxime (ed.); CLÉANTHE; DIOGÈNE LAËRCE; PLUTARQUE; CICÉRON; SÉNĖQUE; ÉPICTÈTE; MARC-AURÈLE. Les stö̈ciens. Trad. Émile Bréhier. Bibliothèque de la Pléiade. Paris: Gallimard, 2002.

SÉNECA, Lucio Anneo. Cartas a Lucilio. Trad., prólogo y notas Vicente López Soto. 3. ed. Barcelona: Juventud, 2006.

SÊNECA. Sobre a tranquilidade da alma/Sobre o ócio. Trad., introdução e notas José Rodrigues Seabra Filho. São Paulo: Nova Alexandria, 2001.

SÉNÈQUE. De la clémence. Trad. et texte établi par François Préchac. 2. ed. Paris: Les Belles Lettres, 1961.

\subsection{Fontes secundárias:}

ARNOLD, Edward Vernon. Roman stoicism: being lectures on the history of the stoic philosophy with special reference to its development within the roman empire. Freeport: Books for Libraries, 1971.

BALDRY, Harold C. Zeno's ideal state. Journal of hellenic studies. London: Society for the Promotion of Hellenic Studies, n. 79, pp. 3-15, 1959.

BERRAONDO, Juan. El estoicismo: la limitación interna del sistema. Montesinos: Barcelona, 1992.

BRÉHIER, Émile. Chrysippe et l'ancien stö̈cisme. Paris: Presses Universitaires de France, 1951.

BRUN, Jean. 0 estoicismo. Trad. João Amado. Lisboa: Edições 70, 1986.

CLASTRES, Pierre. Arqueologia da violência. Trad. Carlos Eugênio Marcondes de Moura. São Paulo: Brasiliense, 1982.

DINIZ, Marcio Augusto de Vasconcelos. 0 princípio de legitimidade do poder no direito público romano e sua efetivação no direito público moderno. Rio de Janeiro: Renovar, 2006.

ERSKINE, Andrew. The hellenistic stoa: political thought and action. Ithaca: Cornell University, 1990.

FASSÒ, Guido. Storia della filosofia del diritto. Vol I: antichità e medioevo. Roma-Bari: Gius. Laterza \& Figli, 2001.

FAVEZ, Charles. Les opinions de Sénèque sur la femme. Revue des Études Latines. Paris: Les Belles Lettres, t. XVI, pp. 335-345, 1938.

FAVEZ, Charles. Un féministe romain: Musonius Rufus. Bulletin de la Societé des Études de Lettres. Lausanne: Université de Lausanne, n. 20, pp. 1-8, 1933. 
GAZOLLA, Rachel. 0 ofício do filósofo estóico: o duplo registro da stoa. São Paulo: Loyola, 1999.

GONÇALVES, Ana Teresa Marques. Uma análise da obra De clementia de Sêneca: a noção de virtude. Phoînix. Rio de Janeiro: UFRJ, n. 5, pp. 51-74, 1999.

HEGEL, Georg Wilhelm Friedrich. Fenomenologia do espírito. Trad. Paulo Meneses; com a colaboração de Karl-Heinz Efken e José Nogueira Machado. 7. ed. rev. Petrópolis: Vozes; Bragança Paulista: UFS, 2002.

INW00D, Brad. Hierocles: theory and argument in the second century AD. Oxford Studies in Ancient Philosophy. Oxford: Oxford University, n. 2, pp. 151-184, 1984.

LIMA VAZ, Henrique Cláudio de. Escritos de filosofia IV: introdução à ética filosófica 1. Loyola: São Paulo, 1999.

LOEWENSTEIN, Karl. Teoría de la constitución. Trad. y estudio Alfredo Gallego Anabitarte. 2. ed. ampl. Barcelona: Ariel, 1986.

MATOS, Andityas Soares de Moura Costa. 0 estoicismo imperial como momento da ideia de justiça: universalismo, liberdade e igualdade no discurso da Stoá em Roma. Rio de Janeiro: Lumen Juris, 2009.

MORRISON, Wayne. Filosofia do direito: dos gregos ao pósmodernismo. Trad. Jefferson Luiz Camargo. Rev. técnica Gildo Sá Leitão Rios. São Paulo: Martins Fontes, 2006.

ONFRAY, Michel. Cinismos: retrato de los filósofos llamados perros. Trad. Alcira Bixio. Buenos Aires: Paidós, 2005.

PARENTE, Margherita Isnardi. Ierocle stoico: oikeiosis e doveri sociali. In: HAASE, Wolfgang; TEMPORINI, Hildegard. (orgs.). Aufstieg und Niedergang der Römischen Welt. T. II., vol. 36.3, pp. 2201-2226. Berlin/New York: Walter de Gruyter, 1989.
RECASÉNS SICHES, Luis. Tratado general de filosofía del derecho. 4. ed. México: Porrúa, 1970.

REYDAMS-SCHILS, Gretchen. The roman stoics: self, responsibility and affection. Chicago: University of Chicago, 2005.

RODRIGUES, Antonio Medina. A Eneida virgiliana entre a vivência e a narração. Introdução a VIRGÍlIO. Eneida. Trad. e notas Odorico Mendes. Estabelecimento do texto, notas e glossário de Luiz Alberto Machado Cabral. Cotia: Ateliê; Campinas: Unicamp, 2005.

SALDANHA, Nelson Nogueira. As formas de governo e o ponto de vista histórico. Belo Horizonte: Universidade de Minas Gerais, 1960.

SCHOFIELD, Malcolm. The stoic idea of the city. With a new foreword by Martha Craven Nussbaum. Chicago: University of Chicago, 1999.

SELLARS, John. Stoicism. Berkeley: University of California, 2006.

STEPHENS, William 0. Epictetus on how the stoic sage loves. Oxford Studies in Ancient Philosophy. Oxford: 0xford University, n. 14, pp. 193-210, 1996.

TATAKIS, Basile N. Panétius de Rhodes, le fondateur du moyen stoicisme: sa vie et son oeuvre. Paris: J. Vrin, 1931.

VEYNE, Paul. Séneca y el estoicismo. Trad. Mónica Utrilla. México: Fondo de Cultura Económica, 1996.

VIZENTIN, Marilena. Imagens do poder em Sêneca: estudo sobre o De clementia. Cotia: Ateliê; São Paulo: FAPESP, 2005.

Recebido em novembro de 2011. Aprovado em fevereiro de 2012. 